\title{
Allogeneic and xenogeneic interactions in reef-building corals may induce tissue growth without calcification
}

\author{
Uri Frank $^{1, *}$, Itzchak Brickner ${ }^{2,4}$, Baruch Rinkevich ${ }^{1}$, Yossi Loya ${ }^{2}$, Rolf P. M. Bak ${ }^{3}$, \\ Yair Achituv ${ }^{4}$, Micha Ilan ${ }^{2}$
}

${ }^{1}$ The National Institute of Oceanography, Israel Oceanographic and Limnological Research, PO Box 8030, Haifa 31080, Israel

${ }^{2}$ Department of Zoology, The George S. Wise Faculty of Life Sciences, Tel Aviv University, Tel-Aviv 69978, Israel

${ }^{3}$ Netherlands Institute for Sea Research, PO Box 59, 1790 AB Den Burg, Texel, The Netherlands; and Institute of Systematics and Population Biology, University of Amsterdam, Mauritskade 61, PO Box 94766, 1090 GT Amsterdam, The Netherlands

${ }^{4}$ Faculty of Life Sciences, Bar Ilan University, Ramat Gan 52900, Israel

\begin{abstract}
Tissue growth without the deposition of calcium carbonate skeletons was recorded in 2 Red Sea hermatypic cnidarians during competitive interactions. Tissue contacts between allogeneic colonies of the hydrocoral Millepora dichotoma resulted in unilateral overgrowth. In $39 \%$ of the assays the overgrowing tissue did not secrete a skeleton for up to $10 \mathrm{wk}$. These tissues were loosely attached to the overgrown branch, and rapidly advanced by up to $25 \mathrm{~mm}$ within the first $2 \mathrm{wk}$. Thereafter, tissue growth slowed down or stopped and calcium carbonate was deposited over the subordinate branch, starting at the original contact area. In xenogeneic interactions between the scleractinian coral Cyphastrea chalcidicum and the cirriped barnacle Savignium dentatum, tissues of the coral always overlaid the plates of the barnacle without depositing calcium carbonate as long as the barnacles were alive (up to $5 \mathrm{yr}$ ). Calcium carbonate was deposited by the coral's tissue on the barnacle's plates only following barnacle death. In both cases, the non-calcifying overgrowing tissues lacked polyps but appeared normal in histological sections and contained typical cnidarian cells and endosymbiotic zooxanthellae. This type of tissue growth without calcification is a newly described allogeneic/xenogeneic response elicited by hermatypic cnidarians.
\end{abstract}

KEY WORDS: Coral · Cirripedia · Growth · Calcification · Competitive interactions · Histocompatibility

\section{INTRODUCTION}

Hermatypic cnidarians are the most important framework builders in modern tropical reef communities (Fagerstrom 1987). Tissue growth in this group of organisms is considered to be closely associated with calcification, the deposition of aragonitic calcium carbonate by the overlying calicoblastic, ectodermal layer (Barnes \& Chalker 1990). Moreover, the most frequently used methods to estimate coral growth rates, such as alizarin red staining (Barnes 1970, Lamberts 1978), buoyant weight measurements (Bak 1973

\footnotetext{
•E mail: euben@vmsa.technion.ac.il
}

Jokiel et al. 1978, Davies 1989) and incorporation of the radioactive isotope ${ }^{14} \mathrm{C}$ (Rinkevich \& Loya 1984), are related to the deposition of skeletons rather than to the growth of tissues. Tissue growth without calcification in hermatypic cnidarians or free tissue movements above already deposited skeletons have only rarely been documented, although Brown et al. (1994) observed periodical withdrawal of coral tissues into the calices as a response to air exposure during low tides.

Hard substratum for settlement and growth is probably a limited resource for sessile reef invertebrates such as hermatypic corals, which are known to compete for space during their growth (Jackson \& Buss 1975, Sheppard 1985, Lang \& Chornesky 1990). This competition is expressed as a complex array of antago- 
nistic responses against conspecifics, as well as against unrelated organisms. During these interactions, various competitive processes, some of which are still poorly understood, occur on the morphological, cellular and biochemical levels (e.g. nematocyst discharge, development of mesenterial filaments and sweeper tentacles, allelopathic interactions, unidirectional translocation of photosynthates, unilateral and reciprocal overgrowth: Bak et al. 1982, Rinkevich \& Loya 1983, Chornesky 1991, Salter-Cid \& Bigger 1991, ChadwickFurman \& Rinkevich 1994, Frank \& Rinkevich 1994, Rinkevich et al. 1994). Overgrowth during both allogeneic and xenogeneic interactions is one of the most common and well-documented competitive mechanisms. In calcareous cnidarians, such overgrowth has always been marked by simultaneous tissue formation and skeleton deposition as in the regular growth pattern (e.g. Potts 1976, Bak \& Criens 1982, Rinkevich \& Loya 1983, Chornesky 1991, Chadwick-Furman \& Rinkevich 1994).

Tissues and skeletons of living hermatypic cnidarians also serve as substrata for a variety of parasitic and commensal sessile invertebrates (Patton 1976, Morton 1983). Several groups of invertebrates, such as serpulid tubeworms (Strathmann et al. 1984, DeVantier et al. 1986, ten Hove 1989, Marsden et al. 1990, Frank \& ten Hove 1992), cirriped crustaceans (Ross \& Newman 1973), molluscs (Morton 1983) and sponges (Wulf \& Buss 1979), are known to inhabit the living surfaces of hydrocorals and madreporarians. These epibionts exhibit a variety of mechanisms to avoid overgrowth by the coral's tissue and skeleton (Hiro 1938, Gohar \& Soliman 1963, Ross \& Newman 1973, Morton \& Scott 1980, Anderson 1992, Brickner 1994).

Here we describe the phenomenon of tissue growth without calcium carbonate deposition in 2 Indo-Pacific hermatypic cnidarians, Millepora dichotoma (Hydrozoa) and Cyphastrea chalcidicum (Anthozoa), which develops following allogeneic and xenogeneic interactions, respectively. Allogeneic contacts between $M$. dichotoma colonies are usually followed by rapid overgrowth of one colony over the other (Frank \& Rinkevich 1994). In some cases, however, we observed allogeneic overgrowths which were not associated with calcification. Xenogeneic interactions between the scleractinian coral $C$. chalcidicum and the barnacle Savignium dentatum occur in about $84 \%$ of all coral colonies near Eilat, in the Red Sea (Brickner 1994). The barnacle bases are embedded within the coral skeleton and their plates are covered by the coral's tissue up to the rims of the barnacle aperture (Ross \& Newman 1973). This coral tissue covering the barnacle's plates does not deposit calcium carbonate as does normal tissue (Brickner 1994).

\section{MATERIALS AND METHODS}

All field work was carried out by SCUBA diving in the shallow-water ( 3 to $6 \mathrm{~m}$ ) coral reef adjacent to the H. Steinitz Marine Biology Laboratory at Eilat, Israel $\left(29^{\circ} \mathrm{N}, 35^{\circ} \mathrm{E}\right)$ on the Red Sea. The fringing reefs of the northern Gulf of Eilat are characterized by high coral coverage and species diversity (Loya 1972).

Branches (ramets), about $10 \mathrm{~cm}$ long each, were removed in the field from 9 large Millepora dichotoma colonies (identified as A to I) using wire cutters. The isolated ramets were secured to plastic clothespins that had been pre-glued to $5 \times 20 \mathrm{~cm}$ Plexiglas plates. Ramets from 6 colonies ( $A$ to $F$ ) were arranged in pairs, in 2 replicates each of all 15 possible pairwise combinations. Ramets from 3 colonies ( $G$ to I) were paired in 8 replicates each of all 3 possible pair combinations. The tips of adjacent branches in each allogeneic pair were carefully put in gentle direct contact. This procedure minimizes injury to contacting tissues, as indicated by in situ follow-up observations on allogeneic pairs, which displayed healthy tissue with extending polyps as in other branch tips. One isogeneic control assay was set up for each of the 9 studied colonies. Interacting branches were observed in situ every 10 to $14 \mathrm{~d}$ for up to $12 \mathrm{wk}$ following the first tissue-to-tissue contact. A pair of branches was vitally stained with alizarin red S dye in situ every 3 to $4 \mathrm{wk}$ (10 to $15 \mathrm{mg}$ $\mathrm{I}^{-1}, 24 \mathrm{~h}$ : Lamberts 1978). Plexiglas plates bearing the pairs of interacting colonies were put into $30 \mathrm{l}$ transparent plastic bags, into which $30 \mathrm{mg}$ of dissolved powdered dye was injected. For histological studies, contacting pairs of branches were fixed in $2.5 \%$ glutaraldehyde in sea-water at room temperature for 3 to $4 \mathrm{~h}$. Non-calcifying overgrowing tissues, which were loosely attached to the overgrown branch, were then removed using fine forceps, rinsed in double distilled water (DDW), dehydrated with increasing concentrations of ethanol and embedded in glycol methacrylate plastic. Sections ( 1 to $2 \mu \mathrm{m}$ ) were prepared using glass knives and stained with hematoxylin and eosin (Bancroft et al. 1990). Control sections were prepared from naive $M$. dichotoma branches after decalcifying the skeletons in a formic acid/sodium citrate solution (Rinkevich \& Loya 1979).

Ten colonies of the scleractinian coral Cyphastrea chalcidicum infested by the pyrgomatide barnacle Savignium dentatum were marked in situ with plastic tags along a $10 \mathrm{~m}$ transect and used for 2 experiments. In the first, 5 coral colonies were stained with alizarin red $\mathrm{S}$ dye as described above. Immediately thereafter, coral tissues were removed using a jet of tap water. Newly calcified zones were visualized under a stereomicroscope as pink-reddish areas (Lamberts 1978). Plates of 5 bamacles were taken from 2 of these 
colonies in order to record coral calcification on the plates. Tissue residues were removed by soaking the plates in concentrated household bleach (sodium hypochlorite) for several hours. Subsequently they were rinsed in DDW, mounted on aluminum stubs using conductive glue, coated with gold palladium and observed with a JEOL JSM 840 scanning electron microscope (SEM). In the second experiment, 30 barnacles of various sizes from the other 5 coral colonies were killed without harming their shells, by inserting a sharp metal needle into their apertures. After $14 \mathrm{~d}$ the alizarin red staining protocol was carried out on the 5 coral colonies, and the barnacles were observed under the stereomicroscope. SEM preparations were made from several plates of the previously killed barnacles. Histological sections from $C$. chalcidicum tissues overgrowing the plates of live barnacles, and from regular coral tissue, were prepared following decalcification as described.

\section{RESULTS}

\section{Allogeneic interactions in Millepora dichotoma}

Tissue fusion was evident in all Millepora dichotoma isograft assays within 1 to $3 \mathrm{wk}$ after initial tissue-totissue contact. Allogeneic combinations did not reveal any tissue fusion (cf. Frank \& Rinkevich 1994). Primary incompatible allogeneic responses (Frank \& Rinkevich 1994) in all $18 \mathrm{M}$. dichotoma colony-combinations were recorded as unilateral overgrowths, starting only a few days following tissue-to-tissue contacts (Table 1). Most (83.3\%) outcomes of replicate pairs were consistent in terms of type of response and the directionality of overgrowth. In 7 pair combinations (17 assays $38.9 \%$ of all combinations), the overgrowing tissues of 6 of the 9 studied colonies (all except colonies B, G and $\mathrm{H}_{\text {; }}$ Table 1) started to develop without any sign of a simultaneous calcification process. In the field they were recognized as loosely attached, delicate sheets of tissue over the subordinate (= overgrown) branches (Fig. 1), which could be peeled off easily with a fingernail. These non-calcifying sheets of tissue advanced on the other colony's branch by up to $25 \mathrm{~mm}$ from the contact area within the first $15 \mathrm{~d}$ (combination BD: Table 1). This was 12 times faster than the most rapid calcifying pair ( $2 \mathrm{~mm}$; combination CF: Table 1). After 2 wk the average extent of growth of non-calcifying tissues $(13.4 \pm 8.2 \mathrm{~mm})$ was significantly higher than that of normal calcifying tissues $(1.1 \pm 0.31 \mathrm{~mm}, \mathrm{p}<0.001$; $t$ test). After $6 \mathrm{wk}$, non-calcifying tissues still covered a significantly greater portion of the subordinate branch than did calcifying tissues $(15.4 \pm 7.5$ and $1.6 \pm$ $7.86 \mathrm{~mm}$, respectively; $\mathrm{p}<0.001$ ). After $10 \mathrm{wk}$, all overgrowing tissues which had started as non-calcifying tissues had already deposited calcium carbonate, and the rapid advancement of these tissues slowed down or stopped. Still, these tissues occupied a significantly greater part of the overgrown branch as compared to those that had started as calcifying tissues (16.4 \pm 7.86 and $2.5 \pm 0.97 \mathrm{~mm}$, respectively; $p<0.001$ ). Polyps were not observed in non-calcifying tissues. Histological sections revealed, however, that the overgrowing

Table 1 Primary allogeneic responses between Millepora dichotoma conspecifics as recorded after 2, 6 and 10 wk following initial tissue-to-tissue contact. Numbers of replicates are given; numbers in parentheses (only for colonies $\mathrm{A}$ to F) indicate the average overgrowth distance in $\mathrm{mm}$. < and > indicate overgrowth directionality; Ca: calcification; NCa: no calcification

\begin{tabular}{|c|c|c|c|}
\hline Combination & After $2 w k$ & After $6 \mathrm{wk}$ & After $10 \mathrm{wk}$ \\
\hline$A B$ & $2 \mathrm{~A}>\mathrm{B}, \mathrm{NCa} ;(5)$ & $2 \mathrm{~A}>\mathrm{B}, \mathrm{NCa} ;(7)$ & $2 \mathrm{~A}>\mathrm{B}, \mathrm{Ca} ;(7)$ \\
\hline $\mathrm{AC}$ & $2 \mathrm{~A}>\mathrm{C}, \mathrm{Ca} ;(<1)$ & $2 \mathrm{~A}>\mathrm{C}, \mathrm{Ca}_{i}(<1)$ & $2 \mathrm{~A}>\mathrm{C}, \mathrm{Ca} ;(1)$ \\
\hline $\mathrm{AD}$ & $2 \mathrm{~A}>\mathrm{D}, \mathrm{Ca} ;(1)$ & $2 \mathrm{~A}>\mathrm{D}, \mathrm{Ca} ;(2)$ & $2 \mathrm{~A}>\mathrm{D}, \mathrm{Ca} ;(3)$ \\
\hline $\mathrm{AE}$ & $2 \mathrm{~A}<\mathrm{E}, \mathrm{Ca} ;(<1)$ & $2 \mathrm{~A}<\mathrm{E}, \mathrm{Ca} ;(1)$ & $2 \mathrm{~A}<\mathrm{E}, \mathrm{Ca} ;(2)$ \\
\hline $\mathrm{AF}$ & $2 \mathrm{~A}<\mathrm{F}, \mathrm{NCa}_{i}(6)$ & $2 \mathrm{~A}<\mathrm{F}, \mathrm{NCa} ;(9)$ & $2 \mathrm{~A}<\mathrm{F}, \mathrm{Ca}_{i}(10)$ \\
\hline $\mathrm{BC}$ & $2 \mathrm{~B}>\mathrm{C}, \mathrm{Ca}_{i}(<1)$ & $2 \mathrm{~B}>\mathrm{C}, \mathrm{Ca} ;(2)$ & $2 \mathrm{~B}>\mathrm{C}_{1} \mathrm{Ca}_{i}(3)$ \\
\hline $\mathrm{BD}$ & $2 \mathrm{~B}<\mathrm{D}, \mathrm{NCa}_{i}(25)$ & $2 \mathrm{~B}<\mathrm{D}, \mathrm{NCa}_{i}(25)$ & $2 \mathrm{~B}<\mathrm{D}, \mathrm{Ca} ;(25)$ \\
\hline $\mathrm{BE}$ & $2 \mathrm{~B}<\mathrm{E}, \mathrm{Ca}_{i}(<1)$ & $2 \mathrm{~B}<\mathrm{E}, \mathrm{Ca}_{i}(2)$ & $2 \mathrm{~B}<\mathrm{E}, \mathrm{Ca}_{i}(3)$ \\
\hline $\mathrm{BF}$ & $2 \mathrm{~B}<\mathrm{F}, \mathrm{Ca} ;(<1)$ & $2 \mathrm{~B}<\mathrm{F}_{i} \mathrm{Ca}_{i}(<1)$ & $2 \mathrm{~B}<\mathrm{F}, \mathrm{Ca} ;(3)$ \\
\hline$C D$ & $2 \mathrm{C}<\mathrm{D}, \mathrm{Ca} ;(<1)$ & $2 \mathrm{C}<\mathrm{D}, \mathrm{Ca}_{i}(2)$ & $2 \mathrm{C}<\mathrm{D}, \mathrm{Ca}_{i}(3)$ \\
\hline $\mathrm{CE}$ & $2 \mathrm{C}>\mathrm{E}_{1} \mathrm{NCa}_{;}(17)$ & $2 \mathrm{C}>\mathrm{E}_{1} \mathrm{NCa}_{;}(20)$ & $2 \mathrm{C}>\mathrm{E}_{1} \mathrm{Ca}_{;}(23)$ \\
\hline CF & $2 \mathrm{C}<\mathrm{F}_{1} \mathrm{Ca}_{i}(2)$ & $2 \mathrm{C}<\mathrm{F}, \mathrm{Ca}_{i}(4)$ & $2 \mathrm{C}<\mathrm{F}, \mathrm{Ca}_{i}(4)$ \\
\hline DE & $2 \mathrm{D}<\mathrm{E}, \mathrm{NCa}_{i}(14)$ & $2 \mathrm{D}<\mathrm{E}_{1} \mathrm{NCa}_{i}(16)$ & $2 \mathrm{D}<\mathrm{E}_{1} \mathrm{NCa}_{i}(17)$ \\
\hline DF & $2 \mathrm{D}>\mathrm{F}, \mathrm{Ca} ;(1)$ & $2 \mathrm{D}>\mathrm{F}, \mathrm{Ca}_{i}(1)$ & $2 \mathrm{D}>\mathrm{F}_{i} \mathrm{Ca}_{i}(2)$ \\
\hline EF & $2 \mathrm{E}<\mathrm{F}, \mathrm{Ca} ;(<1)$ & $2 \mathrm{E}<\mathrm{F}, \mathrm{Ca} ;(1)$ & $2 \mathrm{E}<\mathrm{F}, \mathrm{Ca}_{i}(1)$ \\
\hline $\mathrm{GH}$ & $6 \mathrm{G}>\mathrm{H}, \mathrm{Ca}_{i} 2 \mathrm{G}<\mathrm{H}, \mathrm{Ca}$ & $6 \mathrm{G}>\mathrm{H}, \mathrm{Ca} ; 2 \mathrm{G}<\mathrm{H}, \mathrm{Ca}$ & $6 \mathrm{G}>\mathrm{H}, \mathrm{Ca} ; 2 \mathrm{G}<\mathrm{H}, \mathrm{Ca}$ \\
\hline GI & $2 \mathrm{G}<\mathrm{I}, \mathrm{NCa} ; 6 \mathrm{G}<\mathrm{I}, \mathrm{Ca}$ & $2 \mathrm{G}<\mathrm{I}, \mathrm{NCa} ; 6 \mathrm{G}<\mathrm{I}, \mathrm{Ca}$ & $2 \mathrm{G}<\mathrm{I}, \mathrm{Ca}$ \\
\hline $\mathrm{HI}$ & $5 \mathrm{H}<\mathrm{I}, \mathrm{NCa} ; 3 \mathrm{H}<\mathrm{I}, \mathrm{Ca}$ & $5 \mathrm{H}<\mathrm{I}, \mathrm{NCa} ; 3 \mathrm{H}<\mathrm{I}, \mathrm{Ca}$ & $3 \mathrm{H}<\mathrm{I}, \mathrm{NCa} ; 5 \mathrm{H}<\mathrm{I}, \mathrm{Ca}$ \\
\hline
\end{tabular}



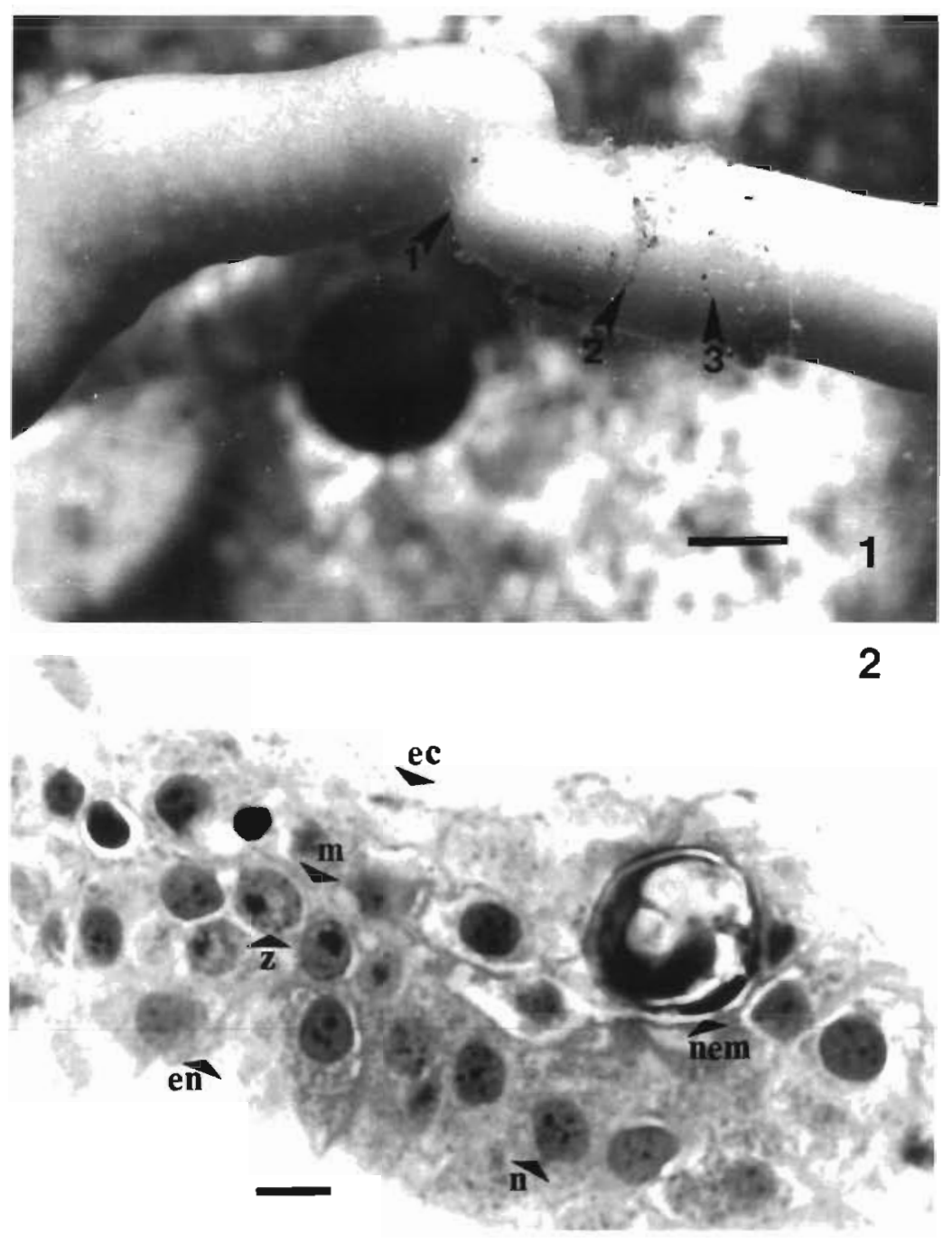

Figs. 1 \& 2. Millepora dichotoma. Fig. 1. Allogeneic overgrowth, 4 wk following initial tissue-to-tissue contact. Tissue growth without calcification has been followed by calcification, starting from the original contact area. Arrowheads indicate the original contact area (1), edge of calcifying overgrowing tissue (2) and non-calcifying tussue (3). Scale bar $=10 \mathrm{~mm}$. Fig. 2. Cross section $(2 \mu \mathrm{m})$ through overgrowing tissue without calcification (hematoxylin and eosin). ec: ectoderm; en: endoderm; m: mesoglea; $n$ : nucleus of endodermal celli nem: nematocyst; $z$ : zooxanthella cell. Scale bar $=10 \mu \mathrm{m}$

rapid advancement of the 'superior' colony's tissue slowed down significantly or even stopped, and calcium carbonate was deposited, starting at the tip area of the original tissue-to-tissue contact. This result was then confirmed by in situ observations (Fig. 1) and by alizarin red staining (pink-reddish color on the overgrown tips of the subordinate branch).

\section{Xenogeneic interactions between Cyphastrea chalcidicum and Savig- nium dentatum}

The plates of all living Savignium dentatum inhabiting Cyphastrea chalcidicum colonies were found to be covered by homogeneous zooxanthellate coral tissue without calcification when observed under the stereomicroscope. Polyps were absent on the plates of all living barnacles (Figs. 3 to 5). The coral tissue advanced up to the barnacle's aperture, and was tightly attached to the barnacle's plates. This type of overgrowth differs, therefore, from the loosely attached non-calcifying Millepora dichotoma tissue envelopes that arise during allogeneic encounters. All studied colonies of C. chalcidicum stained well and evenly with alizarin red, as expected for a hemispheric colony. However, the plates of all living barnacles remained white and did not stain at all, indicating that no calcium carbonate was deposited by the overlying coral tissue. SEM preparations from plates of living $S$. dentatum revealed only a few, limited spots of calcified material of coral origin (data not shown), which might explain the tight

tissues contained endosymbiotic zooxanthellae, nematocyts and other cell types, arranged in ectodermal and endodermal cell layers as in regular $M$. dichotoma tissue (Fig 2). The skeletons of the subordinate branches below the non-calcifying allogeneic sheets of tissue did not stain with alizarin red, indicating that no new calcium carbonate was deposited there. In contrast, other branch termini, including those which were overgrown by tissue and skeletons (37 assays; Table 1), stained weakly pink-reddish. The primary allogeneic responses in the non-calcifying overgrowth assays were usually completed within 2 wk. Thereafter, the attachment of the coral tissue to the plates. Even limited coral calcification over the barnacle plates can be easily seen because the radial strands and projections which are characteristic of the plates for $S$. dentatum are not visible if covered by coral skeleton (Figs. 3 to 6). Plates from dead individuals, on the other hand, were always covered by calcium carbonate of coral origin (Figs. 4 \& 6) and stained well with alizarin red. Their apertures were almost completely sealed by coral skeleton already $3 \mathrm{wk}$ after their death (Fig. 4). Histological sections of $C$. chalcidicum did not reveal any significant difference between calcifying and non- 

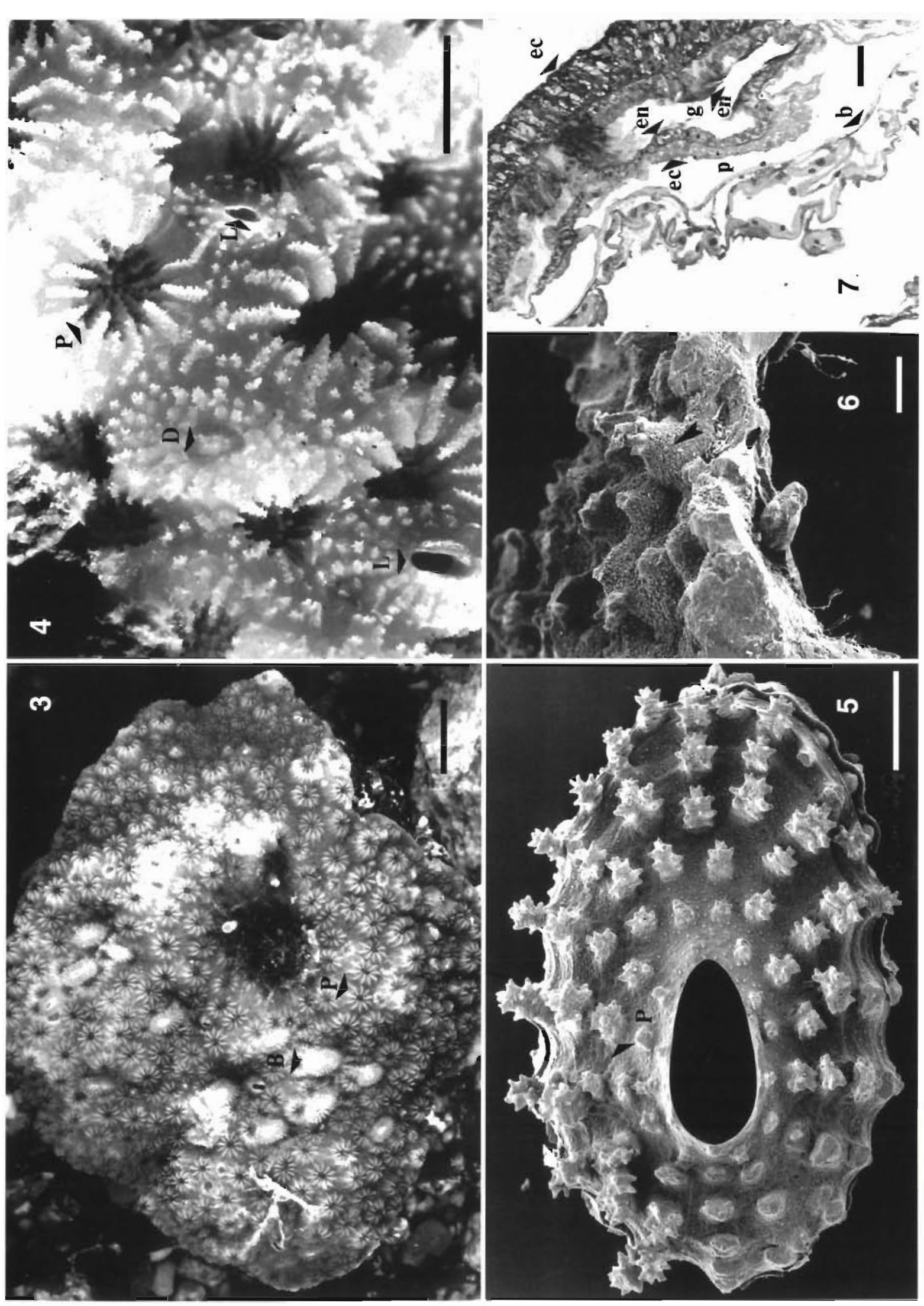

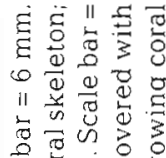
ब $8 \stackrel{0}{0} 3$

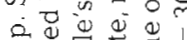
중 记䓃吉

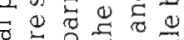
总吉䓃导

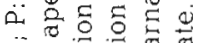
岛 
calcifying tissues, except of the lack of polyps in the latter (Fig. 7). Cross sections of coral tissue overgrowing living $S$. dentatum plates clearly demonstrated the typical structure of the inter-polyp madreporarian tissue, consisting of 2 body walls separated by a gastric cavity (Fig. 7). Typical cnidarian cells were arranged in ectodermal and endodermal cell layers in each body wall. Symbiotic zooxanthellae were observed within endodermal cells, which had a normal appearance, like those of the control sections.

\section{DISCUSSION}

We have documented here the occurrence of growth without calcium carbonate deposition in 2 hermatypic cnidarians, Millepora dichotoma and Cyphastrea chalcidicum, engaged in allogeneic and xenogeneic interactions, respectively. These species represent 2 distinct classes of the Cnidaria: $M$. dichotoma belongs to the Hydrozoa, C. chalcidicum to the Anthozoa. The phylogenetic distance between these 2 species within the Cnidaria suggests that growth without calcification is not a unique phenomenon, and may be expressed by other reef-building corals as well.

Unilateral overgrowth by tissue without calcification or polyp development in allogeneic encounters of Millepora dichotoma was a temporary phase during the establishment of primary allogeneic responses. It was always followed by development of regular calcifying tissue and polyps, usually within the 4 to $10 \mathrm{wk}$ following initial tissue-to-tissue contact. The noncalcifying tissue advanced rapidly over the subordinate branch and was loosely attached to it until calcification began. Overgrowth by non-calcifying tissue extended for significantly greater distances over the subordinate branches, as compared to the regular calcium-carbonate-depositing tissue (Table 1). The absence of polyps is probably attributable to the extremely rapid growth. This rapid tissue advancement, without calcification or polyp development, may therefore be regarded as a newly described allogeneic effector mechanism that evolved for rapid occupation of substratum. The efficiency of this type of growth is well demonstrated by the significantly greater areas occupied on the subordinate branches by non-calcifying tissues as compared to normal calcifying tissues. Similar responses involving rapid growth without calcification are also found in other hermatypic corals in cases of rapid regeneration after tissue lesions, and produce features referred to as 'lip of tissue' (Bak et al. 1977, Bak \& Steward-Van Es 1980). The overgrowing tissue slowly eliminates the tissue of the subordinate branch by the expression of unknown effector mechanisms, or indirectly by drastically reducing light and nutrient supply, as has been suggested by Ivker (1972) for allogeneic interactions between Hydractinia echinata conspecifics. Calcium carbonate is probably deposited by the overgrowing partner only on clean areas of the subordinate colony's skeleton. Rapid overgrowth without calcification was displayed in at least 1 combination by only 6 colonies out of the 9 studied (Table 1). The occurrence of non-calcifying tissue in only some of the combinations, and its high degree of reproducibility within repeatable assays of the same combinations (except for $\mathrm{GI}$ and $\mathrm{HI}$; Table 1), suggest that a specific genotype-combination is required for this effector mechanism to be expressed. Similar specificity has also been recorded for other effector mechanisms in the scleractinian corals Stylophora pistillata and Acropora hemprichi (Chadwick-Furman \& Rinkevich 1994 and Rinkevich et a1. 1994, respectively).

Overgrowth of Savignium dentatum plates by Cyphastrea chalcidicum tissue without skeleton deposition and polyp development is probably the result of a different mechanism. The non-calcifying coral tissue above the barnacle's plates, which probably provides protection against predation (Patton 1976), was found to be a long-term situation, lasting as long as the barnacle lives (up to 5 yr: Brickner 1994). Death of the barnacle was immediately followed by calcium carbonate deposition by the overgrowing coral tissue and eventually by appearance of coral polyps above the plates. On living barnacles, calcium carbonate deposition by the overgrowing coral tissue may prevent the barnacle's growth by cementing the sutures between plates and bases (Ross \& Newman 1973), and eventually may reduce food and oxygen supply by sealing the aperture. S. dentatum presumably possesses some physiological-biochemical mechanisms to prevent skeleton deposition by the overgrowing $C$. chalcidicum tissue.

We suggest that tissue growth without calcification, as observed in the 2 hermatypic species studied here, reflects 2 similar end products of 2 different biological processes with unlike ecological backgrounds. Growth without calcification in Millepora dichotoma was probably triggered in the superior partner as a result of tissue contact with a specific allogeneic colony. In Cyphastrea chalcidicum, on the other hand, growth without skeleton deposition was induced by the overgrown barnacle Savignium dentatum. The non-calcifying tissues were histologically indistinguishable from regular tissues overlying skeleton in both studied species. One may therefore assume that the calcificationinhibiting agent directly prevents the precipitation of calcium carbonate at the biochemical level and not by obstructing the development of a normal calicoblastic layer. The rapid calcification of $C$. chalcidicum tissue immediately following the barnacle's death supports this hypothesis. Rapid overgrowth without skeleton 
deposition is an allogeneic effector mechanism in $M$. dichotoma, and the inhibition of calcium carbonate deposition in C. chalcidicum by S. dentatum is a xenogeneic effector mechanism, induced by the barnacle. As such, neither phenomenon has been described previously. They should be taken into account in future coral growth and competition studies.

Acknowledgements. We thank the staff of the $\mathrm{H}$. Steinitz Marine Biology Laboratory in Eilat for diving facilities and hospitality. Yaacov Langsam (Department of Electron Microscopy, Bar Ilan University) is kindly acknowledged for making the SEM preparations. Funds were provided by the GIF, the German-Israeli Foundation for Scientific Research and Development (B.R.)

\section{LITERATURE CITED}

Anderson DT (1992) Structure, function and phylogeny of coral-inhabiting barnacles (Cirripedia, Balanoidea). Zool J Linn Soc 106:277-339

Bak RPM (1973) Coral weight increment in-situ. A new method to determine coral growth. Mar Biol 20:45-49

Bak RPM, Brouns JJWM, Heys FML (1977) Regeneration and aspects of spatial competition in the scleractinian corals Agaricia agaricites and Montastrea annularis. In: Taylor DL (ed) Proc 3rd Int Symp Coral Reefs, Vol 1. School of Marine and Atmospheric Sciences, University of Miami, Miami, p 143-148

Bak RPM, Criens SR (1982) Experimental fusion in Atlantic Acropora (Scleractinia). Mar Biol Lett 3:67-72

Bak RPM, Steward Van Es Y (1980) Regeneration of superficial damage in the scleractinian corals Agaricia agaricites, f purpurea and Porites astreoides. Bull mar Sci 30: 883-887

Bak RPM, Termaat RM, Dekker R (1982) Complexity of cora] interaction: influence of time, location of interaction and epifauna. Mar Biol 69:215-222

Bancroft ID, Stevens A, Turner DR (1990) Theory and practice of histological techniques. Churchill Livingstone, Edinburgh

Barnes DJ (1970) Coral skeletons: an explanation for their growth and structure. Science 170:1305-1308

Barnes DJ, Chalker BE (1990) Calcification and photosynthesis in reef-building corals and algae. In: Dubinsky $Z$ (ed) Ecosystems of the world; coral reefs. Elsevier, Amsterdam, p $109-131$

Brickner I (1994) Ecology, systematics and phylogenetics of coral inhabiting barnacles in the Gulf of Eilat. PhD thesis, Bar Ilan University, Ramat Gan (in Hebrew with English summary)

Brown BE, Le Tissier MDA, Dunne RP (1994) Tissue retraction in the scleractinian coral Coeloseris mayeri, its effect upon coral pigmentation, and preliminary implications for heat balance. Mar Ecol Prog Ser 105:209-218

Chadwick Furman NE, Rinkevich B (1994) A complex allorecognition system in a reef building coral: delayed responses, reversals and nontransitive hierarchies. Coral Reefs 13:57-63

Chornesky EA (1991) The ties that bind: inter-clonal cooperation may help a fragile coral dominate shallow highenergy reefs. Mar Biol 109:41-51

Davies PS (1989) Short-term growth measurements of corals using an accurate buoyant weighing technique. Mar Ecol Prog Ser 101:389-395
DeVantier LM, Reichelt RE, Bradbury RH (1986) Does Spirobranchus giganteus protect host Porites from predation by Acanthaster planci: predator pressure as a mechanism of coevolution? Mar Ecol Prog Ser 32:307-310

Fagerstrom JA (1987) The evolution of reef communities. John Wiley \& Sons, New York

Frank U, Rinkevich B (1994) Nontransitive patterns of historecognition phenomena in the Red Sea hydrocoral Millepora dichotoma. Mar Biol 118:723-729

Frank U, ten Hove HA (1992) In vitro exposure of Spirobranchus giganteus and $S$ tetraceros (Polychaeta, Serpulidae) to various turbidities; branchial morphologies an expression of filtering strategy? Oebalia 18:45-52

Gohar HAF, Soliman GN (1963) On three mytilid species boring in living corals. Publ Mar Biol Stn Ghardaqa, Red Sea $12: 65-98$

Hiro F (1938) Studies on the animals inhabiting reef corals II. Cirripeds of the genera Creusia and Pyrgoma. Palao Trop Biol Stn Stud 1:391-416

Ivker FB (1972) A hierarchy of histo-incompatibility in Hydractinia echinata. Biol Bull 143:162-174

Jackson JBC, Buss L (1975) Allelopathy and spatial competition among coral reef invertebrates. Proc Natl Acad Sci USA 72:5160-5163

Jokiel PL, Maragos JE Franzisket L (1978) Coral growth: buoyant weight technique. In: Stoddard DR, Johannes RE (eds) Coral reefs: research methods. UNESCO, Paris, p $529-541$

Lamberts AE (1978) Coral growth: alizarin method. In: Stoddard DR, Johannes RE (eds) Coral reefs: research methods. UNESCO, Paris, p 523-527

Lang JC, Chornesky EA (1990) Competition between scleractinian reef corals - a review of the mechanism and effects. In: Dubinsky Z (ed) Ecosystems of the world; coral reefs. Elsevier, Amsterdam, p 209-252

Loya $Y(1972)$ Community structure and species diversity of hermatypic corals at Eilat, Red Sea. Mar Biol 13:100-123

Marsden JR, Conlin BE, Hunte W (1990) Habitat selection in the tropical polychaete Spurobranchus giganteus II. Larval preference for corals. Mar Biol 104:93-99

Morton B (1983) Coral-associated bivalves of the Indo Pacific. In: Russell Hunter WD (ed) The Mollusca, Vol 6. Academic Press, Orlando, p 139-224

Morton B, Scott PJB (1980) Morphological and functional specialisations of the shell, musculature and pallial glands in the Lithophaginae (Mollusca: Bivalvia). J Zool, Lond 192: $179-203$

Patton WK (1976) Animal associates of living reef corals. In: Jones OA, Endean R (eds) Biology and geology of coral reefs, Vol 3. Academic Press, New York, p 1-36

Potts DC (1976) Growth interactions among morphological variants of the coral Acropora palifera. In: Mackie GO (ed) Coelenterate ecology and behavior. Plenum Press, New York, p 79-88

Rinkevich B, Frank U, Bak RPM, Müller WEG (1994) Alloimmune responses between Acropora hemprichi conspecifics: nontransitive patterns of overgrowth and delayed cytotoxicity. Mar Biol 118:731-737

Rinkevich B, Loya Y (1979) The reproduction of the Red Sea coral Stylophora pistillata. I. Gonads and planulae. Mar Ecol Prog Ser 1:133-144

Rinkevich B, Loya Y (1983) Intraspecific competitive networks in the Red Sea coral Stylophora pistillata. Coral Reefs 1: $161-172$

Rinkevich B, Loya Y (1984) Coral illumination through an optic glass-fiber: incorporation of ${ }^{14} \mathrm{C}$ photosynthates. Mar Biol 80:7-15 
Ross A, Newman W (1973) Revision of the coral inhabiting barnacles (Cirripedia: Balanidae). Trans San Diego Soc Nat Hist 17:137-174

Salter-Cid L, Bigger CH (1991) Alloimmunity in the gorgonian coral Swiftia excerta. Biol Bull 181:127-134

Sheppard CRC (1985) Unoccupied substrate in the central Great Barrier Reef: role of coral interactions. Mar Ecol Prog Ser 25:259-268

Strathmann RR, Cameron RA, Strathmann MF (1984) Spiro-

This article was submitted to the editor branchus giganteus (Pallas) breaks a rule for suspensionfeeders. J exp mar Biol Ecol 79:245-249

ten Hove HA (1989) Serpulinae (Polychaeta) from the Caribbean: IV Pseudovermilia madracicola sp.n., a symbiont of corals. Studies in honour of Dr. Pieter Wagenaar Hummelinck. Found Scient Res Surinam Neth Antilles 123:135-144

Wulf JL. Buss LW (1979) Do sponges help hold coral reefs together? Nature 281:474-475

Manuscript first received: October 31, 1994

Revised version accepted: February 24, 1995 